Published in final edited form as:

Gut. 2011 September ; 60(9): 1177-1235. doi:10.1136/gut.2010.221440.

\title{
To resect or not to resect? That is the question
}

\author{
Mazen Noureddin ${ }^{1}$, David E Kleiner ${ }^{2}$, Ahmed M Gharib ${ }^{3}$, Gennady Bratslavsky ${ }^{4}$, and Theo \\ Heller $^{1}$ \\ ${ }^{1}$ Liver Diseases Branch, The National Institute of Diabetes and Digestive and Kidney Diseases, \\ National Institutes of Health, Maryland, USA \\ 2Laboratory of Pathology, National Cancer Institute, National Institutes of Health, Maryland, USA \\ ${ }^{3}$ Integrative Cardiovascular Imaging Section, The National Institute of Diabetes and Digestive and \\ Kidney Diseases, National Institutes of Health, Maryland, USA \\ ${ }^{4}$ Urologic Oncology Branch, National Cancer Institute, National Institutes of Health, Maryland, \\ USA
}

\section{CLINICAL PRESENTATION}

A 54-year-old Caucasian female, with a strong family history of renal cell carcinoma, presented with a left kidney lesion. She had a hysterectomy 20 years ago and no significant history of oral contraceptive use. During the current evaluation, she was found to have two hypervascular lesions in the left lobe of the liver in addition to a fatty liver on CT scan as well as MRI (figure 1A-C). The largest lesion was $2 \mathrm{~cm}$ in size. She was asymptomatic. Physical examination showed an obese woman with body mass index of 35.6 with an otherwise normal exam. Her laboratory results showed an aspartate aminotransferase of 88 $\mathrm{U} / \mathrm{l}$, alanine aminotransferase of $75 \mathrm{U} / 1$, alkaline phosphatase of $93 \mathrm{U} / 1$, total bilirubin of 0.6 $\mathrm{mg} / \mathrm{dl}$ and direct bilirubin of $0.2 \mathrm{mg} / \mathrm{dl}$. Her albumin, leucocytes, haemoglobin and platelets were all normal. She underwent a left nephrectomy. She also underwent a hepatectomy of segments 2 and 3 due to suspicion of metastatic disease. The pathology from the liver lesions is shown in figures 2 and 3.

\section{QUESTION}

What is the diagnosis of the liver lesions?

\footnotetext{
Correspondence to Dr Mazen Noureddin, Liver Diseases Branch, The National Institute of Diabetes and Digestive and Kidney Diseases, National Institutes of Health, 10 Center Drive, Bldg 10 Room 4-5722, Clinical Center, Bethesda, Maryland 20892, USA; noureddinm@niddk.nih.gov.

Competing interests None.

Patient consent Obtained.

Ethics approval This study was conducted with the approval of the NIH IRB.

Provenance and peer review Not commissioned; externally peer reviewed.
} 


\section{ANSWER}

Figure 4 shows an irregular distribution of steatotic hepatic parenchyma with dilated vessels embedded within a fibrosis stroma. The surrounding liver showed steatohepatitis and early fibrosis. These are the typical pathological findings of telangiectatic adenoma (TA).

Benign hepatic liver tumours are classically divided into hepatic adenoma (HA) and focal nodular hyperplasia (FNH). Telangiectatic adenomas (TAs) were originally classified as telangiectatic focal nodular hyperplasia. Recent molecular studies have led pathologists to reclassify telangiectatic adenoma as hepatic adenomas. ${ }^{1} \mathrm{TA}$ is typically associated with obesity and steatosis. ${ }^{2}$ Paradis et al showed that $19 \%$ of TA had cellular atypia and one of them had hepatocellular carcinoma (HCC). Other reports have also suggested that TA is associated with obesity and may progress to HCC. ${ }^{3}$ Dokmak et al showed that $10 \%$ of TAs progressed to HCC. This risk was associated with an adenoma size of larger than $5 \mathrm{~cm} .{ }^{4}$ Our patient had TA that was associated with steatohepatitis and obesity. TA should be suspected when mass lesions are discovered in the setting of obese patients with evidence of fatty liver disease. This is particularly important given recent advances in classification of adenomas and evidence for the development of possible malignancy.

\section{Acknowledgments}

Funding The Intramural Research Program of the NIH, National Cancer Institute, Center for Cancer Research and NIDDK.

\section{REFERENCES}

1. Mizushima N, Levine B, Cuervo AM, et al. Autophagy fights disease through cellular self-digestion. Nature. 2008; 451:1069-75. [PubMed: 18305538]

2. Yoshimori T, Noda T. Toward unraveling membrane biogenesis in mammalian autophagy. Curr Opin Cell Biol. 2008; 20:401-7. [PubMed: 18472412]

3. Alonso S, Pethe K, Russell DG, et al. Lysosomal killing of Mycobacterium mediated by ubiquitinderived peptides is enhanced by autophagy. Proc Natl Acad Sci USA. 2007; 104:6031-6. [PubMed: 17389386]

4. Gutierrez MG, Master SS, Singh SB, et al. Autophagy is a defense mechanism inhibiting BCG and Mycobacterium tuberculosis survival in infected macrophages. Cell. 2004; 119:753-66. [PubMed: 15607973]

5. Jia K, Thomas C, Akbar M, et al. Autophagy genes protect against Salmonella typhimurium infection and mediate insulin signaling-regulated pathogen resistance. Proc Natl Acad Sci USA. 2009; 106:14564-9. [PubMed: 19667176]

6. Lapaquette P, Glasser AL, Huett A, et al. Crohn's disease-associated adherent-invasive E. coli are selectively favoured by impaired autophagy to replicate intracellularly. Cell Microbiol. 2010; 12:99-113. [PubMed: 19747213]

7. Levine B. Eating oneself and uninvited guests: autophagy-related pathways in cellular defense. Cell. 2005; 120:159-62. [PubMed: 15680321]

8. Paludan C, Schmid D, Landthaler M, et al. Endogenous MHC class II processing of a viral nuclear antigen after autophagy. Science. 2005; 307:593-6. [PubMed: 15591165]

9. Schmid D, Pypaert M, Munz C. Antigen-loading compartments for major histocompatibility complex class II molecules continuously receive input from autophagosomes. Immunity. 2007; 26:79-92. [PubMed: 17182262] 
10. Hampe J, Franke A, Rosenstiel P, et al. A genome-wide association scan of nonsynonymous SNPs identifies a susceptibility variant for Crohn disease in ATG16L1. Nat Genet. 2007; 39:207-11. [PubMed: 17200669]

11. Rioux JD, Xavier RJ, Taylor KD, et al. Genome-wide association study identifies new susceptibility loci for Crohn disease and implicates autophagy in disease pathogenesis. Nat Genet. 2007; 39:596-604. [PubMed: 17435756]

12. Cadwell K, Liu JY, Brown SL, et al. A key role for autophagy and the autophagy gene Atg1611 in mouse and human intestinal Paneth cells. Nature. 2008; 456:259-63. [PubMed: 18849966]

13. Travassos LH, Carneiro LA, Ramjeet M, et al. Nod1 and Nod2 direct autophagy by recruiting ATG16L1 to the plasma membrane at the site of bacterial entry. Nat Immunol. 2010; 11:55-62. [PubMed: 19898471]

14. Cooney R, Baker J, Brain O, et al. NOD2 stimulation induces autophagy in dendritic cells influencing bacterial handling and antigen presentation. Nat Med. 2010; 16:90-7. [PubMed: 19966812]

15. Saitoh T, Fujita N, Jang MH, et al. Loss of the autophagy protein Atg16L1 enhances endotoxininduced IL-1beta production. Nature. 2008; 456:264-8. [PubMed: 18849965]

16. Ferwerda G, Kramer M, de Jong D, et al. Engagement of NOD2 has a dual effect on proIL-1beta mRNA transcription and secretion of bioactive IL-1beta. Eur J Immunol. 2008; 38:184-91. [PubMed: 18157816]

17. van Heel DA, Ghosh S, Butler M, et al. Muramyl dipeptide and toll-like receptor sensitivity in NOD2-associated Crohn's disease. Lancet. 2005; 365:1794-6. [PubMed: 15910952]

18. Netea MG, Nold-Petry CA, Nold MF, et al. Differential requirement for the activation of the inflammasome for processing and release of IL-1beta in monocytes and macrophages. Blood. 2009; 113:2324-35. [PubMed: 19104081]

19. Tosato G, Jones KD. Interleukin-1 induces interleukin-6 production in peripheral blood monocytes. Blood. 1990; 75:1305-10. [PubMed: 2310829]

20. Zhang YH, Lin JX, Vilcek J. Interleukin-6 induction by tumor necrosis factor and interleukin-1 in human fibroblasts involves activation of a nuclear factor binding to a kappa B-like sequence. Mol Cell Biol. 1990; 10:3818-23. [PubMed: 2192263]

21. Campbell J, Ciesielski CJ, Hunt AE, et al. A novel mechanism for TNF-alpha regulation by p38 MAPK: involvement of NF-kappa B with implications for therapy in rheumatoid arthritis. J Immunol. 2004; 173:6928-37. [PubMed: 15557189]

22. Hsu HY, Wen MH. Lipopolysaccharide-mediated reactive oxygen species and signal transduction in the regulation of interleukin-1 gene expression. J Biol Chem. 2002; 277:22131-9. [PubMed: 11940570]

23. Kuballa P, Huett A, Rioux JD, et al. Impaired autophagy of an intracellular pathogen induced by a Crohn's disease associated ATG16L1 variant. PLoS One. 2008; 3:e3391. [PubMed: 18852889]

24. Hugot JP, Chamaillard M, Zouali H, et al. Association of NOD2 leucine-rich repeat variants with susceptibility to Crohn's disease. Nature. 2001; 411:599-603. [PubMed: 11385576]

25. Ogura Y, Bonen DK, Inohara N, et al. A frame shift mutation in NOD2 associated with susceptibility to Crohn's disease. Nature. 2001; 411:603-6. [PubMed: 11385577] 

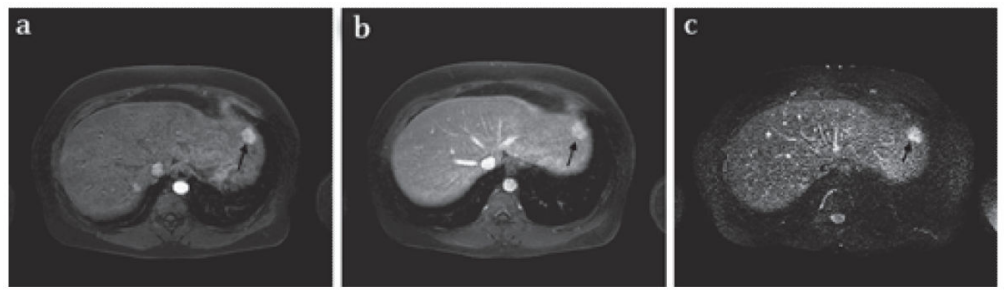

Figure 1.

(A) MRI of the liver showing hyperintensity of one of the lesions (arrow) on T1-weighted gradient echo fat suppressed MR, arterial phase. (B) MRI of the liver showing hyperintensity of one of the lesions (arrow) on T1-weighted gradient echo fat suppressed MR, venous phase. Note the mild washout of the contrast in the lesion compared to the arterial phase image. (C) MRI of the liver on T2-weighted fast spin echo fat suppressed MR, showing strong hyperintensity of the lesion, with absence of central scar. 


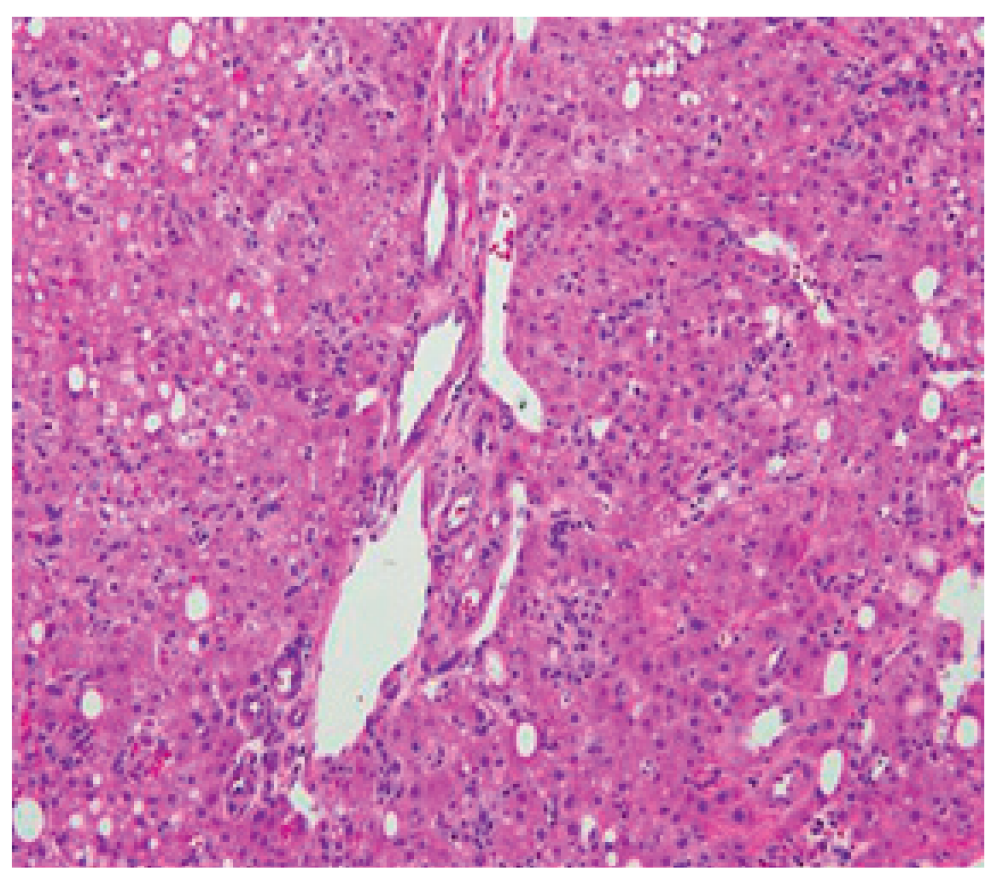

Figure 2.

Section of one of the hepatic masses showing a portal-like area with arteries and veins but no bile ducts. 


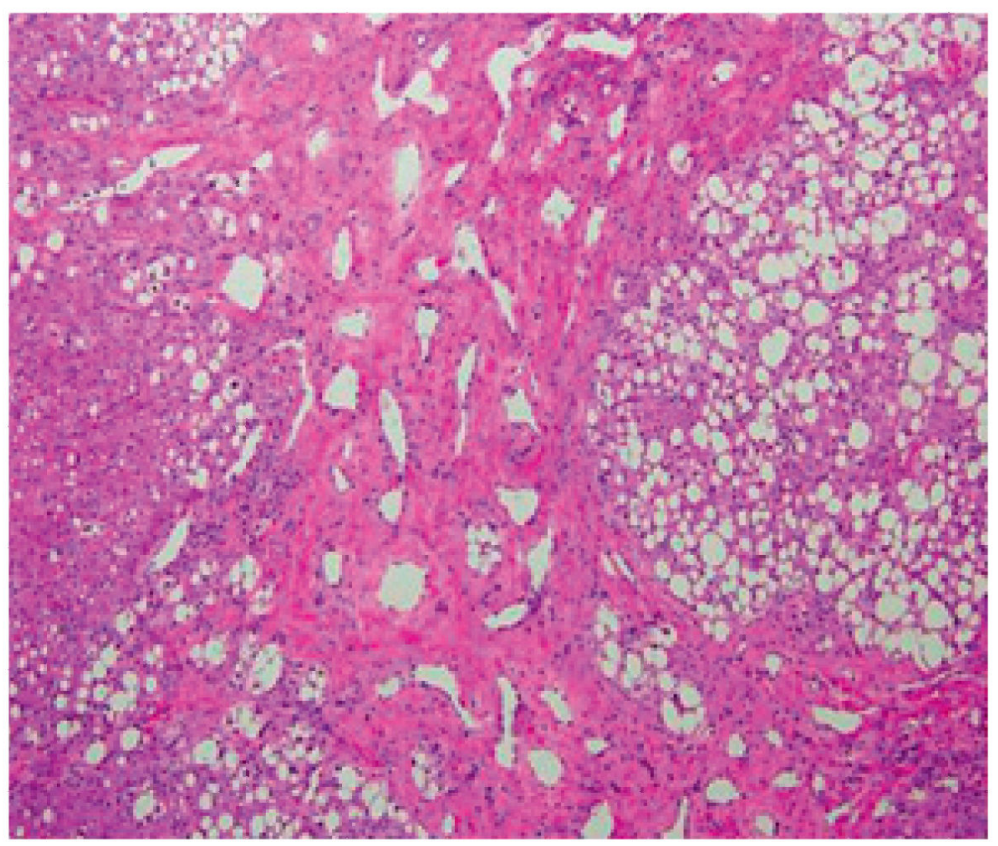

Figure 3.

Haemangoima-like area from the mass. The lesion also showed prominant steatosis. 


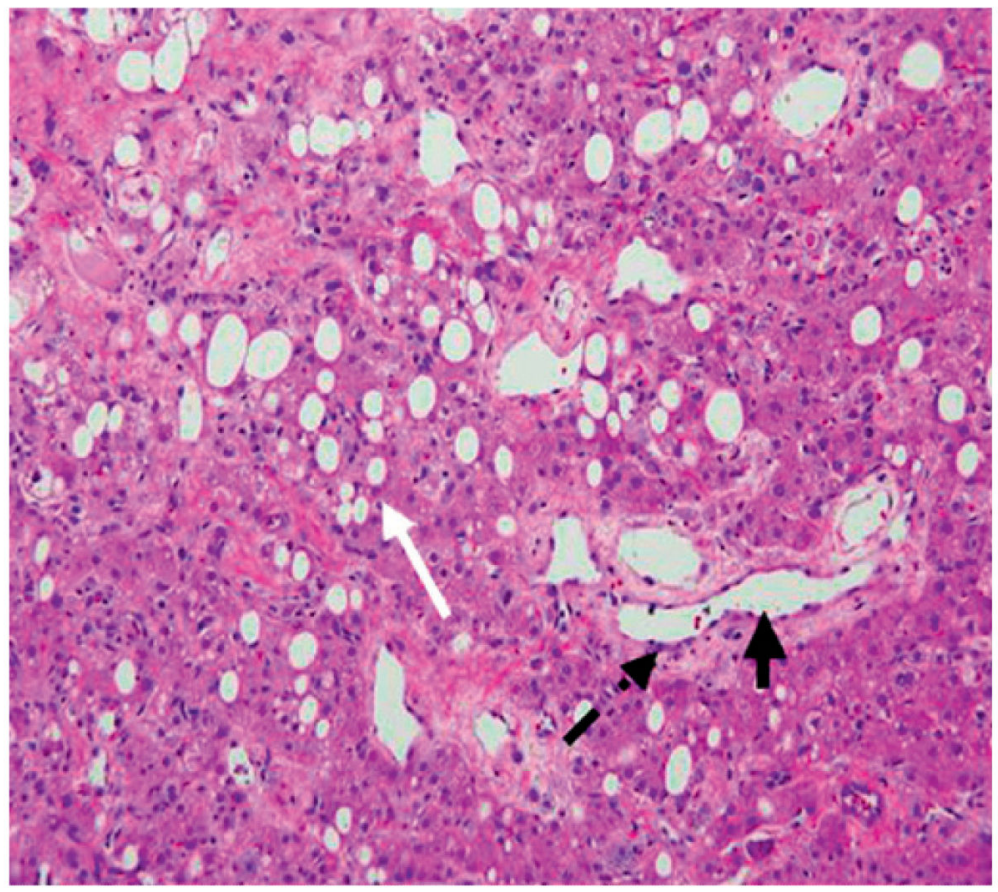

Figure 4.

Dilated vessels (big arrow), parenchyma with fibrosis (dotted arrow) and surrounding steatosis (white arrow) in the adenoma. No bile ducts were present within the lesion. There was no central scar and abnormally formed vessels with myxoid changes were not seen. 